\title{
Analysis Evaluating the Results from the Research of Textbooks' Didactic Efficiency in Technical Education
}

\section{Ján Bajtoš - Iveta Kmecová*}

\begin{abstract}
At present we consider education to be one of the most important permanent priorities which greatly influences the prosperity of all countries. Education should enable students to integrate into the dynamically developing society. In this regard, education is the main factor of social prosperity. Therefore, each school is responsible for the level of education they provide (Bajtoš, Orosová 2011). In our contribution, we present some selected results of the investigation focused on the observation of the didactic efficiency of the textbooks in technical education. We bring in some partial valuation results of the education quality of Economics at the Technical High School in Hlohovec. Further, we bring in the results from the didactic test achieved by a group of students. We compared the results of the students from the "standard" class and the "experimental" class. In the end, we outline the need of upgrading the efficiency of the educational process.
\end{abstract}

Key words: textbook, teaching text, didactic efficiency of the textbook, efficiency of the educational process

\section{Introduction}

Schools should provide quality preparation for the expectant profession. This highly depends on the educational aids - including textbooks. All schools should realize this fact and do the necessary procedures to provide good education. A graduate should obtain education and knowledge corresponding with their field, as well as related fields. Therefore, connecting school with real life is very important (Bajtoš, 2007, Turek, Albert, 2005).

Our ambition to gain efficiency in the educational process (in order to enable students to learn with the least effort possible and obtain optimal results, etc.) is based on the demands of the society in the 21st century. There were many various aspirations, as we know from the history of didactics, e.g. education

\footnotetext{
* Ján Bajtoš, Dubnica Institute of Technology in Dubnica nad Váhom, Dubnica nad Váhom, Slovakia; bajtos@dti.sk Iveta Kmecová, The Technical High School, Hlohovec; kmecova.ivet@gmail.com
} 


\section{Acta Technologica Dubnicae \\ volume 3, 2013, issue 1}

content corrections, implementation of several educational concepts which should adjust or lower the contrast between what schools provide students, and what the age they live in expects from them (Petlák, 2008).

We can make the conclusion from the facts mentioned above, that it is the school that is greatly important for the life of a graduate. Schools should provide students good preparation. It is absolutely necessary for them in order to adopt and develop competences in a correct way.

From this point of view, it is important to observe the didactic efficiency in technical education and, at the same time, we must verify the quality of existing textbooks. If any deficiency is detected, then there is a need of making corrections of the content or designing new educational texts (Bajtoš, 2003, Kmecová, Bajtoš, 2010).

\section{The didactic efficiency research of the textbooks in technical education}

\subsection{Goal of investigation}

The main goal of the investigation was to observe and check the didactic efficiency of the chapters of the Economics textbook that we formed at the Technical High School in Hlohovec and also to check the quality of our teaching text in relation to the results of the educational process in the subject Economics. We formulated these partial goals to fulfil the main goal:

- to learn students' opinions and requests for the existing textbooks of Economics at the school,

- to form a new teaching text for 20 lessons,

- to find out whether the redrafted teaching text is suitable and understandable for students,

- to experimentally check the didactic efficiency of our chapters on a group of students from the 3rd grade of the Technical High School in Hlohovec,

- to learn the results of the teaching process using our chapters compared with the existing textbook,

- to learn the students' attitude to the quality of education,

- to suggest some recommendations how to improve the educational process of Economics.

\subsection{Object of investigation}

The object of our investigation was to check the didactic model of teaching with the use of our textbook's chapters and comparison of its efficiency with one of the existing textbooks, comparison of the students' knowledge and the students' satisfaction with the educational process using our chapters. 


\subsection{The main hypothesis of the investigation}

On the basis of our goals we defined the main hypothesis:

$\mathrm{H}$ : Teaching the subject of Economics using our textbook will be more effective than when using the ordinary textbook.

We divided the main hypothesis into 5 partial ones to be able to verify the main hypothesis.

\subsection{Partial hypotheses}

H1: Students from the "experimental" class will gain better results in the didactic test of Economics than students from the "standard" class.

For the verification of H1, we used cognitive, objective, "NR" test. The achievement of each student was compared with other students.

$\mathrm{H} 2$ : At the end of the experiment, the students in the experimental class will rate the educational process more positively than the students from the standard class.

H3: "Comprehensibility of the formed teaching text evaluated by Cloze test will be higher than $65 \%$."

H4: The comprehensibility of our educational text will be positively rated in the experimental class.

H5: At the end of the experiment, the students in the experimental class will suggest to continue learning the subject of Economics from our newly designed chapters of the textbook.

\subsection{Sample of investigation}

H1: Students from the "experimental" class will gain better results in the didactic test of Economics than students from the "standard" class.

For the verification of H1, we used cognitive, objective, "NR" test. The achievement of each student was compared with other students.

H2: At the end of the experiment, the students in the experimental class will rate the educational process more positively than the students from the standard class.

H3: "Comprehensibility of the formed teaching text evaluated by Cloze test will be higher than $65 \%$."

H4: The comprehensibility of our educational text will be positively rated in the experimental class.

H5: At the end of the experiment, the students in the experimental class will suggest to continue learning the subject of Economics from our newly designed chapters of the textbook. 


\begin{tabular}{|l|c|c|}
\hline Field of study/class & Class & Number of students \\
\hline $\begin{array}{l}\text { Machine engineering } \\
\text { /experimental class }\end{array}$ & III. MSZ & 16 \\
\hline $\begin{array}{l}\text { Electrical engineering } \\
\text { /experimental class }\end{array}$ & III. ET & 10 \\
\hline $\begin{array}{l}\text { Car mechanic } \\
\text { /standard class }\end{array}$ & III. AO & 19 \\
\hline $\begin{array}{l}\text { Mechanic serviceman } \\
\text { Carpenter/standard class }\end{array}$ & III. MOSTEM & 26 \\
\hline Altogether & & $\mathbf{7 1}$ \\
\hline
\end{tabular}

Tab. 1 Investigation sample

\subsection{Methodology}

Before the investigation, there was a research which the aim of which was to find out some opinions and requests of the students about the quality of textbooks in technical education. As a result we obtained some useful information - the level of textbooks' quality before the investigation itself. For the realization of the research on the didactic efficiency of the new Economics textbook, we used the following methods and techniques: natural pedagogical experiment, survey method, Cloze test, didactic test, statistical methods of the elaboration of results and literature study.

\section{Results}

We bring in a selection of results from the research (Kmecová, 2010):

Task 1: What is your attitude to the subject of Economics, should it continue to be taught by using the newly designed educational text? 
Fig. 1 The opinions of students from the experimental class (degree and apprentice form of study together) about teaching Economics using the newly designed educational text

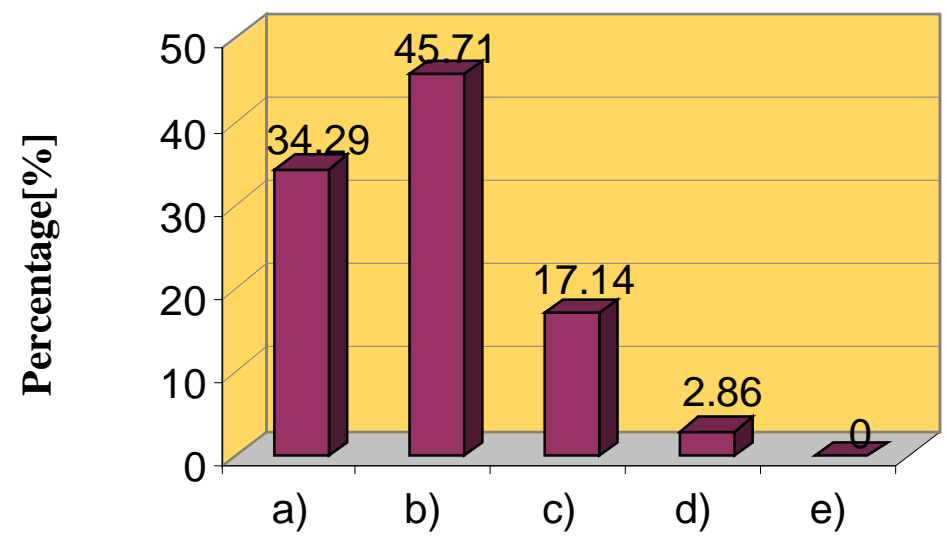

The chances

a) I strongly agree, b) I agree, c) I agree and also disagree, d) I disagree, e) I strongly disagree

The highest percentage of the students from the experimental class $(45.71 \%$, that is 16 out of 35 students) stated b) possibility - I agree that the subject of Economics should be taught by using the newly designed educational text. Overall, $34.29 \%$ of the students chose the possibility a) - I strongly agree. Based on these statements (see Fig. 1), we can allege that hypothesis H5 was confirmed.

\subsection{Statistical verification of the research hypothesis:}

Hypothesis H1 : Students from the „experimental“ class will gain better results in the didactic test of Hypothesis H1: Students from the „experimental“ class will gain better results in the didactic test of Economics than students from the „standard“ class.

For the verification of H1, we used cognitive, objective, "NR" test. The achievement of each student was compared with other students.

In Tab. 2 we bring partial results in the didactic test of students from the degree form of study. 


\begin{tabular}{|c|c|}
\hline \multicolumn{2}{|c|}{ Degree form of study - class } \\
\hline Experimental class & Standard class \\
\hline $\mathrm{n}_{1}=16$ & $\mathrm{n}_{2}=10$ \\
\hline $\bar{X}_{1}[$ body $]=20.75$ & $\bar{X}_{2}[$ body $]=16.60$ \\
\hline$s_{1}^{2}=1.96$ & $S_{2}^{2}=12.71$ \\
\hline$X_{\max }[$ body $]=22$ & $X_{\max }[$ body $]=21$ \\
\hline$X_{\min }[$ body $]=19$ & $X_{\min }[$ body $]=10$ \\
\hline
\end{tabular}

Tab. 2 Results in the didactic test of students from degree form of study

In our investigation, we selected the score of the ascending DT for quantitative sign, in the cognitive area for calculation, non-parametric U-test by Mann and Whitney for big counts.

\begin{tabular}{|c|l|}
\hline $\boldsymbol{H}_{\text {zero }}$ & $\begin{array}{l}\text { There are no differences between the achievement of the students } \\
\text { from the experimental and standard class. }\end{array}$ \\
\hline $\boldsymbol{H}_{\text {alternative }}$ & $\begin{array}{l}\text { There are some differences between the achievement of the students } \\
\text { from the experimental and standard class. }\end{array}$ \\
\hline
\end{tabular}

We compared the calculated figure 11.13 with the critical figure (Chráska, 2007, p. 97).

Calculated figure $\mathrm{u}>1.96$ - than critical figure

We rejected the zero hypothesis at the level of importance 0.05 preferring the alternative hypothesis. There were important statistical differences between students of the "experimental" and "standard" class. This detection was the same for both forms of study.

Concluding statements:

Hypothesis H1 was confirmed (degree and apprentice form of study).

Graphical depiction of the results from the final didactic test in the experimental and standard class (degree and apprentice form of study) - Fig. 2-5. 
Fig. 2 Results from the didactic test of students from experimental class in degree form of study

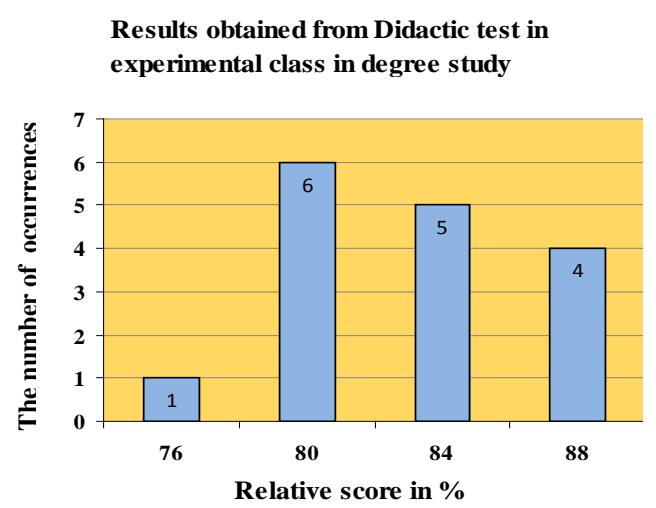

Fig. 4 Results from the didactic test of students from experimental class in apprentice form of study

Results obtained from Didactic test in experimental class in apprentice study

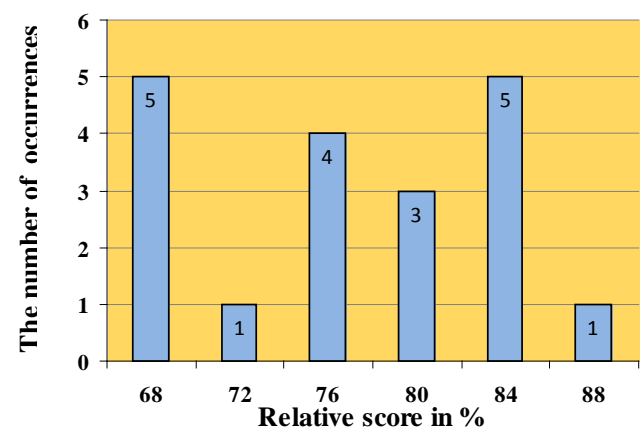

Fig.3 Results from the didactic test of students from standard class in degree form of study

Results obtained from Didactic test in standard class in degree study

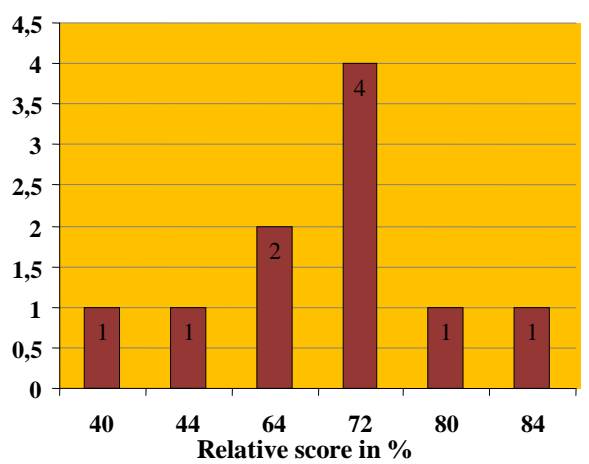

Fig. 5 Results from the didactic test of students from standard class in apprentice form of study

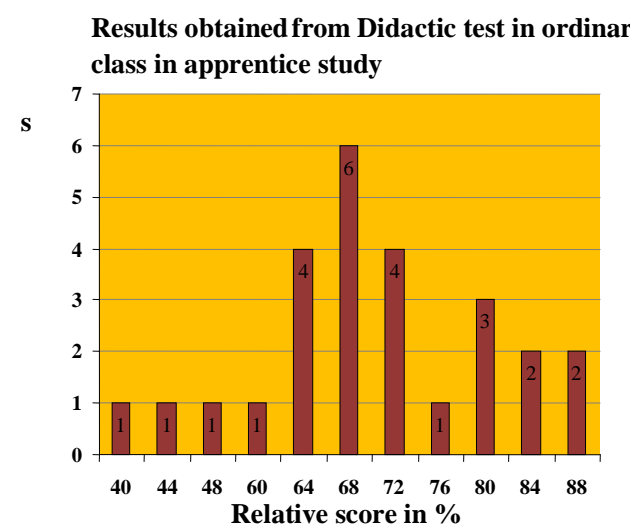

Hypothesis H2: Students from the experimental class will judge the educational process more positively than students from the standard class.

We used the Mann and Whitney U-test for verification. We verified the hypothesis by survey (it consisted of 24 tasks) focused on the education quality 
and the quality of the educational process. We bring in partial results from evaluation of the survey focused on education quality rating.

\section{Analysis of Task 2}

Using the scale 1, 2, 3, 4, 5, 0 (1 - excellent, I am very satisfied, 2 - very good, I am satisfied, 3 - good, sometimes I am satisfied, sometimes not, 4 - bad, I am not satisfied, 5 - very bad, I am not satisfied at all, 0 - I don't know), try to rate following method of economic education.

- work with the textbook

Fig. 6 Attitudes of students from the experimental class (degree study) to the method of education - working with text

123450

Fig. 6 Attitudes of students from the experimental class (degree study) to the method of education - working with text

Experimental class - degree study

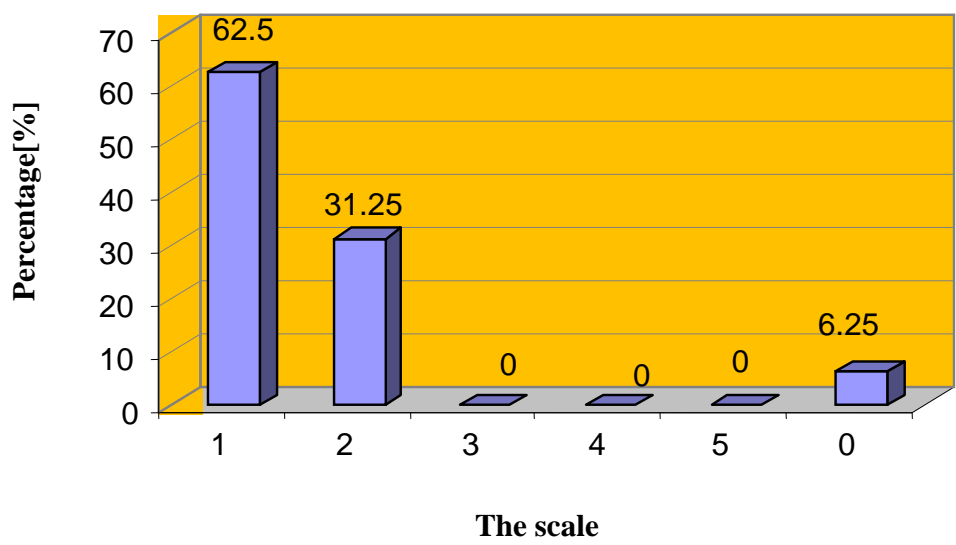

In the experimental group (degree form of study) - $62.50 \%$ respondents rated the method of working with text by mark 1 - excellent and only $6.25 \%$, that is 1 respondent out of 16 stated the mark 0 - I don't know. The results are presented in the Fig. 6. 
Fig. 7 Attitudes of students from the standard class (degree study) to the method of education - working with text

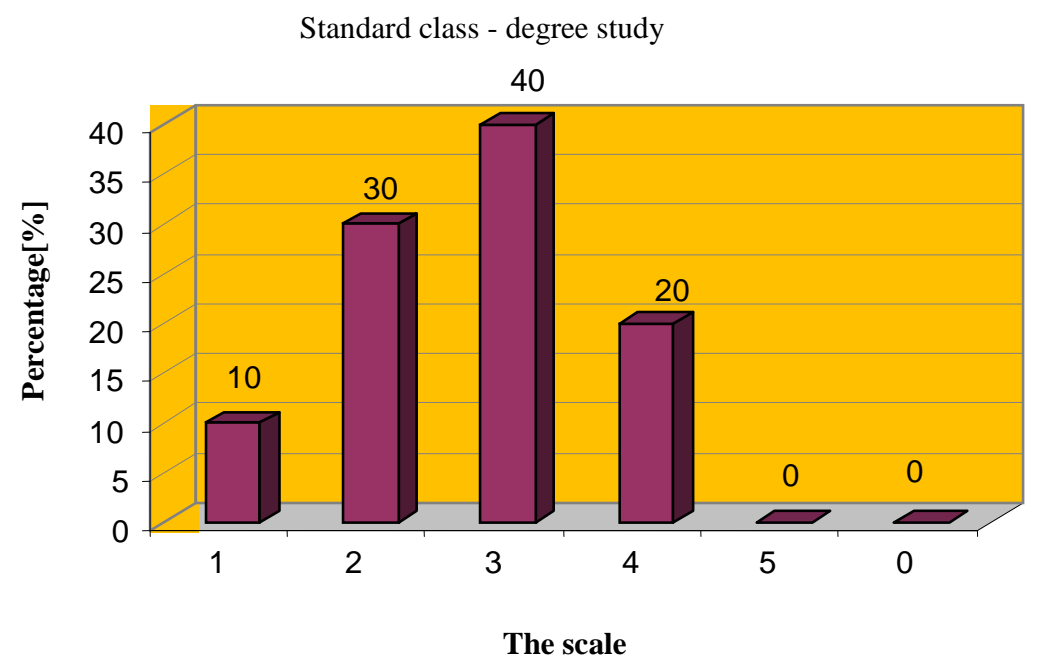

In the standard group ( degree form of study) $-40.00 \%$ respondents rated the current textbook by mark 3 - good and two of them by mark 4 - I am not satisfied. None of the respondents rated this method by marks 5 and 0 . The results are presented in the Fig. 7.

Hypothesis H3: "Comprehensibility of the formed teaching text evaluated by Cloze test will be higher than 65\%."

We verified this hypothesis by Mann and Whitney U-test. The calculated figure 8.46 (apprentice study) and 29.09 (degree study) was higher than the critical figure (in tables) u krit $(0,05)=1.96$, which was the reason of refusing the zero hypothesis and accepting the alternative hypothesis. There were statistically important differences between the number of points in Cloze test from the experimental and standard class (in both forms of study). 
Fig. 8 Average number of completed words in Cloze test in apprentice study experimental and standard class

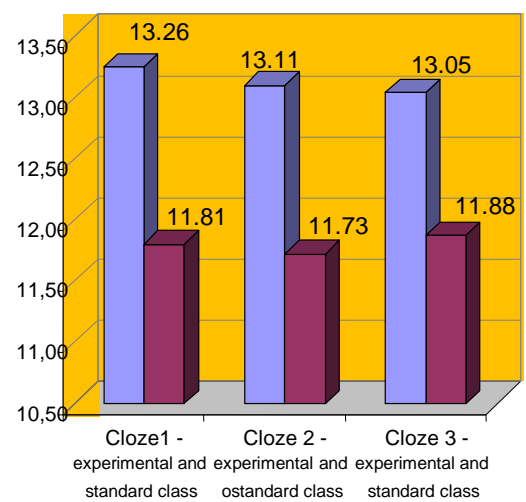

Cloze test (apprentice study)

Fig. 9 Average number of completed words in Cloze test in degree study experimental and standard class

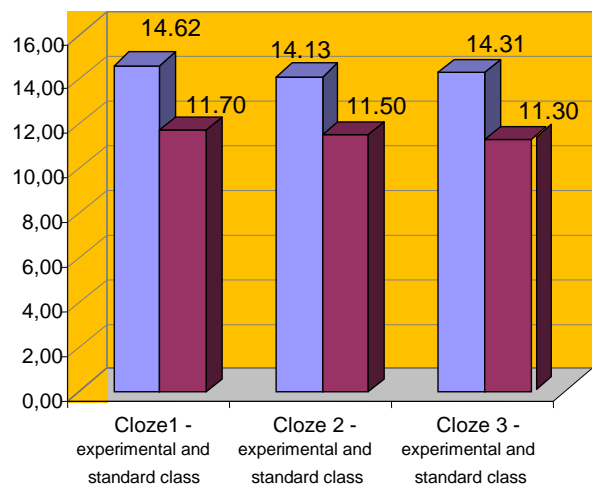

Cloze test (degree study)

In the Fig. 8 and 9, we bring factual results with the numbers of completed words in the experimental and standard class in apprentice and degree study. The students from the experimental class (degree and apprentice form of study) reached more than 13 words at average. The students from the standard class reached in all the three samples less than 13 words. 
Fig. 10 Overall number of words obtained from Cloze test in \%

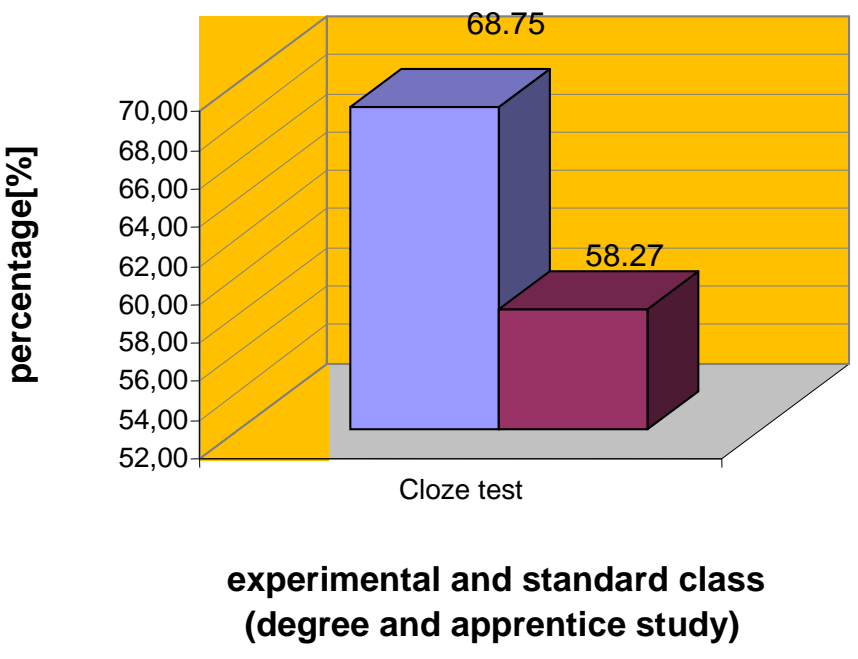

We present overall numbers of words obtained from Cloze test (degree and apprentice form of study altogether) in the Fig.10.We learn from the Fig. 10 that the average number of words in the experimental class (degree and apprentice form of study) was $68.75 \%$, it means more than $65 \%$. We can allege that our own teaching test is comprehensible and easily readable for a student.

Hypothesis H4: The comprehensibility of our educational text will be positively rated in the experimental class.

We verified the $\mathrm{H} 4$ hypothesis by the survey focused on evaluation comprehensibility of the Economics educational test using 4 dimensions of semantic differential (simplicity, structuring, and brevity - sententiousness). The survey was made among students from the experimental class of both forms of study (Turek, 2008, p.321-322).

\section{Discussion}

Hypothesis H1 was confirmed (degree form as well as apprentice form of study). As we can see from the results in Tab. 2, the arithmetic average of the point score reached in didactic test from the experimental class is higher than from the standard class. There were huge differences among the results of the students from the standard class. The difference between the highest and lowest score from the didactic test was 11 points (44\%). The maximum of points in the test 


\section{Acta Technologica Dubnicae \\ volume 3, 2013, issue 1}

was 25. It was approved that students from the "experimental" class will gain better results in the didactic test of Economics than students from the "standard" class.

Hypothesis H2 was confirmed too (degree and apprentice form of study). Students from the experimental class judged the educational process more positively than students from the standard class. Following the analysis of the results in the Fig. 8 and 9 we express the declaration that we managed to confirm the partial Hypothesis H3. The students from the experimental group reached $68.75 \%$ in Cloze test, so the comprehensibility of our text was higher than $65 \%$. Hypothesis H4 was confirmed, too. The comprehensibility of our educational text was positively rated in the experimental class.

\section{Conclusions}

We verified the efficiency of the Economics educational process at the Technical High School in Hlohovec using chapters of the educational text created by us. 71 students acted as a sample for the research - 35 students from the experimental class (together degree and apprentice form of study) and 36 students from the standard class (together degree and apprentice form of study). The main method of the research was natural pedagogical experiment. Further methods and techniques we used: didactic test (for H1 hypothesis verification), survey method (for H2, H4, H5 hypothesis verification), Cloze test (for H3 hypothesis verification) and statistical methods of elaborating the results (Chráska, 2007, Turek, 2008). The presented results obtained from Cloze test suggest that our teaching text is easily readable, more interesting and comprehensible. Our newly formed text was very well accepted and appreciated by the students.

For the educational process we suggest:

- to continue with asking about students' attitudes to the quality of textbooks in technical education,

- to observe and evaluate the didactic efficiency of the textbooks,

- to implement newly created textbooks/educational texts and thus to contribute to the increase of the quality and effectivity of the educational process. 


\section{References}

BAJTOŠ, J.: Kapitoly zo všeobecnej didaktiky. Košice: Equilibria, 2007.

BAJTOŠ, J.: Teória a prax didaktiky. Žilina: Edis, 2003.

BAJTOŠ, J. - OROSOVÁ, R.: Mikrovyučovanie v pregraduálnej príprave učitelov. Košice: Equilibria, 2011. ISBN 978-80-7097-914-3

CHRÁSKA, M.: Metódy pedagogického výzkumu - Základy kvantitatívneho výzkumu. Praha: Grada Publishing, a.s., 2007.

KMECOVÁ, I.: Didaktická účinnost' učebnic vodbornom vzdelávaní. Dizertačná práca 2010. evid.n.: MTF-10901-52770.

KMECOVÁ, I. - BAJTOŠ, J.: Sledovanie didaktickej účinnosti učebníc v odbornom technickom vzdelávaní vyučovacieho predmetu Ekonomika. In: Integrácia teórie a praxe didaktiky ako determinant kvality modernej školy. Zborník príspevkov z medzinárodnej vedeckej konferencie. Košice, 2010.

PETLÁK, E.: Nové tendencie vo vyučovaní. In: Pedagogické rozhl'ady, vol.17, 2008, n. 1.

TUREK, I. - ALBERT, S.: Kvalita školy . Bratislava: STU v Bratislave, 2005.

TUREK, I: 2008. Didaktika. Bratislava: Iura Edition, spol. s r. o, 2008. 